\title{
Corrigendum: Regulation of monocyte cell fate by blood vessels mediated by Notch signalling
}

Jaba Gamrekelashvili, Roberto Giagnorio, Jasmin Jussofie, Oliver Soehnlein, Johan Duchene, Carlos G. Briseño, Saravana K. Ramasamy, Kashyap Krishnasamy, Anne Limbourg, Christine Häger, Tamar Kapanadze, Chieko Ishifune, Rabea Hinkel, Freddy Radtke, Lothar J. Strobl, Ursula Zimber-Strobl, L. Christian Napp, Johann Bauersachs, Hermann Haller, Koji Yasutomo, Christian Kupatt, Kenneth M. Murphy, Ralf H. Adams, Christian Weber \& Florian P. Limbourg

Nature Communications 7:12597 doi: 10.1038/ncomms12597 (2016); Published 31 Aug 2016; Updated 3 May 2017

The authors inadvertently omitted Christine Häger, who was involved in the initial characterization of Notch mutant mice presented in this Article, from the author list and Author contributions statement. These errors have now been corrected in both the PDF and HTML versions of the Article.

(c) (i) This work is licensed under a Creative Commons Attribution 4.0 International License. The images or other third party material in this article are included in the article's Creative Commons license, unless indicated otherwise in the credit line; if the material is not included under the Creative Commons license, users will need to obtain permission from the license holder to reproduce the material. To view a copy of this license, visit http://creativecommons.org/licenses/by/4.0/

(C) The Author(s) 2017 